\title{
Effects of Oxygen on Acetylene Reduction, Cytochrome Content and Respiratory Activity of Azotobacter chroococcum
}

\author{
By J. DROZD AND J. R. POSTGATE \\ A.R.C. Unit of Nitrogen Fixation, University of Sussex, Brighton, BNI $9 Q J$
}

(Accepted for publication 17 June 1970)

\begin{abstract}
SUMMAR Y
The respiratory activities and cytochrome $a_{2}$ contents of nitrogen-fixing continuous cultures of Azotobacter chroococcum ( $\mathrm{NCIB}^{8003}$ ) increased with the partial pressure of oxygen encountered during growth. Above $0.6 \mathrm{~atm}$., wash-out of the culture occurred. Acetylene reduction by culture samples of low respiratory activity was far more easily inhibited by oxygenation than was that of samples of high respiratory activity, though their maximum acetylenereducing activities at their optimal $p \mathrm{O}_{2}$ values were similar. Inhibition by oxygen was reversible after mild oxygenation: 70 to $100 \%$ of the original activity returned immediately when the degree of oxygenation was decreased. Irreversible inhibition occurred after vigorous oxygenation and was associated with a loss of activity in cell-free extracts, which was restored by adding the oxygen-sensitive protein component of Azotobacter nitrogenase. These observations support earlier proposals that augmented respiration can scavenge oxygen from the nitrogen-fixing site and that a conformational change in the state of nitrogenase can prevent damage to the enzyme by oxygen. Vigorous aeration, however, may overcome these protective mechanisms.
\end{abstract}

\section{INTRODUCTION}

Inhibition of growth of nitrogen-fixing Azotobacteriaceae, but not of populations using fixed nitrogen, by oxygen has been known since Meyerhof \& Burk's (I928) report. Dalton \& Postgate (I969a) summarized earlier work and extended the investigation to continuous cultures of Azotobacter chroococcum of known nutritional status. Populations whose growth was limited by availability of the phosphate or carbon + energy source were extremely sensitive to oxygen inhibition; populations whose density was limited by their intrinsic rate of nitrogen fixation (called ' $\mathrm{N}_{2}$ limited' by Dalton \& Postgate, I969 $b$ ) were less oxygen-sensitive, though still much more sensitive than populations assimilating ammonia. Dalton \& Postgate (1969a) assumed that the oxygen sensitivity of Azotobacteriaceae was related to the known oxygen sensitivity of components of nitrogenase (Bulen \& LeComte, I966; Kelly, I $969 a, b$ ) and proposed the hypotheses that: (i) in resting bacteria, the nitrogenase became 'conformationally protected', i.e. it assumed a conformation in which oxygen-sensitive sites were inaccessible to $\mathrm{O}_{2}$; (ii) in growing bacteria, nitrogenase assumed a conformation which would be susceptible to damage by oxygen but that the organism adjusted its respiration rate so as to prevent oxygen reaching sensitive sites. They called this control process 'respiratory protection'. Yates (1970) and Drozd \& Postgate ( I970) observed that growing cultures of A. chroococcum, A. vine- 
landii and Azomonas macrocytogenes partly or completely 'switched-off' nitrogenase activity, assayed as rate of acetylene reduction, when vigorously shaken in air. This process was readily reversed on standing and it represented a possible source of error in the practical application of the acetylene reduction test to nitrogen-fixing aerobes in field conditions described by Stewart, Fitzgerald \& Burris (1967) and Hardy Holsten, Jackson \& Burns (1968).

The concept of an active 'respiratory protection' and a passive 'conformational protection' of nitrogenase in Azotobacter implies that strains of high respiration rate should be more efficient at 'respiratory protection' and less disposed to bring about 'conformational protection'. We report here a study of the oxygen relations of Azotobacter chroococcum 'acclimatized' to high and low $p \mathrm{O}_{2}$ values.

\section{METHODS}

Organisms and medium. Azotobacter chroococcum (NCIB 8003) was grown at $30 \pm 0.5^{\circ}$ in a modification of Burk's medium containing mannitol (Dalton \& Postgate, I969a, $b$ ). To avoid transient precipitation in batches of medium which they described, the $\mathrm{CaCl}_{2}$ was autoclaved separately as a $20 \%$ solution and added aseptically to the rest of the autoclaved medium when cool.

Apparatus. For batch cultures, 250 or $500 \mathrm{ml}$. Erlenmeyer flasks approximately one-quarter full of medium were incubated at $30^{\circ}$ on a rotary shaker; we recognize that such cultures became $\mathrm{O}_{2}$-limited during growth. For continuous culture, apparatus with working volumes of approximately $200 \mathrm{ml}$. (Baker, 1968) were used with a port in the side for a Clark-type oxygen electrode (Protech Ltd, 2 I High Street, Rickmansworth, Hertfordshire). The residual current in the oxygen electrode varied from day to day, so low oxygen tensions were measured by switching off the oxygen supply and stirrer in order to obtain the zero reading; this was then subtracted from the observed value. One port in the lid was closed by a 'Suba-seal' closure for injection of acetylene. Silicone rubber tubing (Esco Rubber Ltd, Seething Lane, London E.C.3) was used for connexions. The initial $\mathrm{pH}$ of the medium was 7.8 and it buffered sufficiently to maintain the $\mathrm{pH}$ value constant at 6.7 in the growth vessel with the populations used, so automatic $\mathrm{pH}$ control was unnecessary. Partial pressures of gases were regulated using gas flowmeters.

Analytical procedures. An estimate of culture density was obtained from its optical density in an Eel 'Spectra' spectrophotometer. To determine organism concentration more exactly, quadruplicate ro $\mathrm{ml}$. samples of culture were centrifuged in dry, weighed, glass centrifuge tubes, washed once in $0.85 \% \mathrm{NaCl}$ and once in distilled water before drying to constant weight in air at $80^{\circ}$. Respiratory activity was measured directly on culture samples in conventional Warburg manometers containing $0.2 \mathrm{ml}$. of $40 \% \mathrm{KOH}$ in the centre well, shaken at 150 strokes $/ \mathrm{min}$., amplitude $2 \mathrm{~cm}$., at $30^{\circ}$. Samples were transferred as rapidly as possible from the culture vessel to the Warburg flask, where they were gassed with argon and oxygen mixtures of the desired $p \mathrm{O}_{2}$. No extra mannitol had to be added. Cytochrome spectra of whole organisms were measured using a diffuse reflectance unit on a Unicam SP 700 spectrophotometer. To allow for non-specific adsorption, peak heights were measured from an interpolated theoretical scatter curve. Protein in culture samples was estimated by the method of Lowry, Rosebrough, Farr \& Randall (195I); protein in crude extracts 
was estimated by the method of Gornall, Bardawill \& David (1949). The standard was bovine serum albumin (Sigma Chemicals Ltd, London).

Acetylene reduction. Acetylene reduction rates were accepted as measures of nitrogenase activity. Samples of culture $(2 \mathrm{ml}$.) were transferred to $25 \mathrm{ml}$. conical flasks and gassed with argon/oxygen mixtures of the desired $p \mathrm{O}_{2}$ value. The flasks were sealed with 'Suba-seal' closures, I ml. of acetylene (freshly prepared from $\mathrm{CaC}_{2}$ and water) was injected and they were shaken at $30^{\circ}$. Gas samples ( $\mathrm{I} \mathrm{ml}$.) were taken by syringe for gas chromatography at 5 or $10 \mathrm{~min}$. intervals and replaced by $\mathrm{I} \mathrm{ml}$. of the appropriate argon and oxygen mixture. This procedure introduced a small systematic error in rate determinations which was unimportant. For tests on samples in Warburg manometer flasks, I ml. acetylene was injected through a vaccine cap (Scientific Furnishings, Chichester) on the side-arm of the manometer flask and gas samples (I ml.) were taken by the same method. With crude extracts (see below) an ATP-generating system was added and acetylene reduction was measured in $8 \mathrm{ml}$. vials under argon as described by Kelly (1969a). The procedures used with continuous cultures are described in the Results section.

Gas chromatography. Ethylene was detected by flame-ionization in a Pye series 104 gas chromatograph with a $5 \mathrm{ft}$ ( $152 \mathrm{~cm}$.) Porapak R. column, $4 \mathrm{~mm}$. internal diameter, at $45^{\circ}$ in a stream of $50 \mathrm{ml} . \mathrm{N}_{2} / \mathrm{min}$. Peak height was taken as being proportional to ethylene concentration.

Preparation of crude cell-free extracts. The culture sample (I00 $\mathrm{ml}$.) was centrifuged at $28,000 \mathrm{~g}$ for $10 \mathrm{~min}$. at $4^{\circ}$. The pellet was resuspended in $10 \mathrm{ml} .0 .025 \mathrm{M}$-tris- $\mathrm{HCl}$ buffer, $\mathrm{pH} 7 \cdot 4$, and disrupted under a stream of nitrogen, while cooled in ice, with a Dawe 'Soniprobe' ultrasonic disintegrator at 2 to $5 \mathrm{~A}$ for $2 \mathrm{~min}$. This preparation was centrifuged at $38,000 \mathrm{~g}$ for $20 \mathrm{~min}$. to give a clear, light-brown supernatant liquid containing nitrogenase and a pellet containing whole bacteria, membranes and other debris. The supernatant was stored under nitrogen and in ice for up to $2 \mathrm{~h}$. before use, or stored in liquid nitrogen for longer periods. 'Fraction 2', the non-haem iron component of nitrogenase, was prepared from Azotobacter chroococcum by Dr M. Kelly in this laboratory.

\section{RESULTS}

\section{Effect of growth $\mathrm{pO}_{2}$ on bacterial density and respiratory rate}

A population of Azotobacter chroococcum was established growing in continuous culture at a dilution rate of $0.2 \mathrm{~h}^{-1}$ under $0.2 \mathrm{~atm}$. oxygen $+0.8 \mathrm{~atm}$. nitrogen from separate cylinders; the combined gas flow rate was I culture vol. $/ \mathrm{min}$. Cytochrome contents, $Q_{\mathrm{O}_{2}}$ values and dry weights were measured on culture samples. The $p \mathrm{O}_{2}$ was then altered and comparable analyses made when the culture was considered to be in a new steady state. Population densities of organisms under various partial pressures of oxygen agreed closely with those obtained by Dalton \& Postgate (I969a) and an almost exact duplicate of their Fig. I was obtained. According to population density measurements, oxygen became the growth-limiting nutrient below a $p \mathrm{O}_{2}$ of 0.09 atm.; above $0.6 \mathrm{~atm}$. $\mathrm{O}_{2}$, wash-out of the culture occurred. Table I shows that the $Q_{\mathrm{o}_{2}}$ values of the organisms increased with increase in growth $p \mathrm{O}_{2}$. 


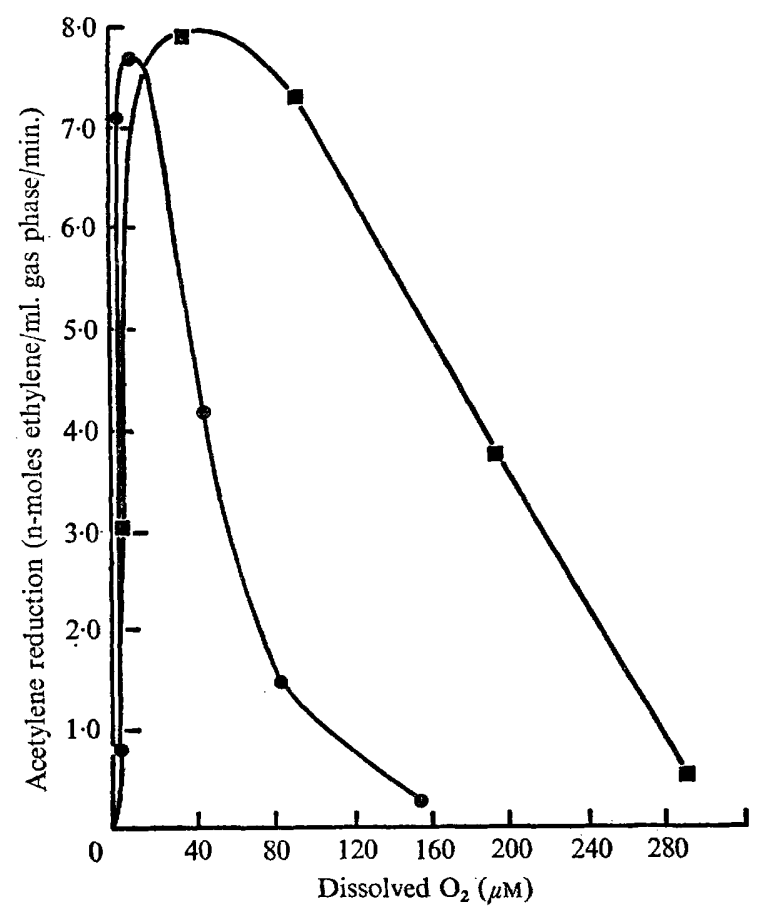

Fig. I. Rates of acetylene reduction at various molarities of dissolved $\mathrm{O}_{2}$ by Azotobacter chroococcum grown in continuous culture at $D=0.2$ h. ${ }^{-1}$. Tests made on whole contents of growth vessel with medium pump off; $\mathrm{O}_{2}$ molarities determined from oxygen electrode readings (see text). Populations grown at 0.09 atm. $\mathrm{O}_{2}(\bullet)$ and at $0.55 \mathrm{~atm} . \mathrm{O}_{2}(\mathbf{m})$.

Table I. Relationship between $\mathrm{pO}_{2}$ of growth, $Q_{\mathrm{o}_{2}}$ and cytochrome content in Azotobacter chroococcum grown in continuous culture under $N_{2}$-fixing conditions at $D=0 \cdot 2 h^{-1}$

$Q_{\mathrm{O}_{2}}$ values of $\mathrm{I} \mathrm{ml}$. samples of culture measured in Warburg flasks at $30^{\circ}$ under $0.6 \mathrm{~atm}$. Ar $+0.4 \mathrm{~atm} . \mathrm{O}_{2}$, with $0.2 \mathrm{ml} .40 \% \mathrm{KOH}$ in the centre well. Cytochrome spectra were measured by diffuse reflectance spectroscopy in a Pye Unicam SP 700 spectrophotometer in cuvettes with a $\mathrm{I} \mathrm{cm}$. light path. Cytochrome levels in the bacteria expressed in terms of extinction $(E)$ at reduced $\alpha$ peak. Bacteria from continuous culture at various $p \mathrm{O}_{2}$ values were centrifuged and resuspended to I I mg. dry wt $/ \mathrm{ml} .0 .025 \mathrm{M}$-tris- $\mathrm{HCl}$ buffer (pH $7 \cdot 4$ ). Reduced spectra obtained by gassing the sample with $\mathrm{H}_{2}$.

$\begin{array}{cccc}\begin{array}{c}\text { Growth } p \mathrm{O}_{2} \\ \text { (atm.) }\end{array} & \begin{array}{c}Q_{\mathrm{O}_{2}} \\ \left(\mu 1 . \mathrm{O}_{2} / \mathrm{mg} . \mathrm{dry}\right. \\ \mathrm{wt} / \mathrm{h} .)\end{array} & \overbrace{a_{2}}^{\begin{array}{c}\text { Cytochrome levels } \\ \left(E \times 10^{3} / \mathrm{mg} . \text { dry wt }\right)\end{array}} \\ 0.05 & 300 & 0.23 & c_{4}+c_{5} \\ 0.10 & 1510 & 0.45 & 5.25 \\ 0.35 & 2300 & 1 \cdot 14 & 6.83 \\ 0.55 & 2700 & 1.36 & 5.60 \\ & & 5.50\end{array}$

Effect of dissolved oxygen on acetylene reduction by whole cultures

The rate of acetylene reduction by whole chemostat cultures was assessed by injecting $20 \mathrm{ml}$. of acetylene into the vessel with the gas inlet and outlet ports clipped off and with the medium pump off (the cultures, of course, ceased to be continuous 
during the test). By adjusting the stirrer manually, the dissolved oxygen level could be held at any selected level below saturation. The rate of acetylene reduction over Io min. was measured at various levels of dissolved oxygen, starting at the highest and then lowering it. Between each determination the culture vessel was flushed out with the gas mixture used for growth. Figure I shows that the optimum concentration of dissolved oxygen for acetylene reduction by culture grown at a $p \mathrm{O}_{2}$ of $0.09 \mathrm{~atm}$. was $\mathrm{I} 2 \mu \mathrm{M}$, though reduction could be detected up to $\mathrm{I} 50 \mu \mathrm{M}$. The culture grown at a $\mathrm{pO}_{2}$ of $0.55 \mathrm{~atm}$. showed an optimum at $25 \mu \mathrm{M}$-oxygen and acetylene reduction could be detected up to $260 \mu \mathrm{M}$.

Effect of ambient $\mathrm{pO}_{2}$ on respiratory rate and acetylene reduction rate of culture samples

Meyerhof \& Burk (1928) reported that respiration in azotobacters is depressed at high $p \mathrm{O}_{2}$ values. The $Q_{\mathrm{O}_{2}}$ values of samples of cultures grown at $p \mathrm{O}_{2} 0.09$ atm. and 0.55 atm. were measured under a range of $\mathrm{pO}_{2}$ values in the manometer flask.

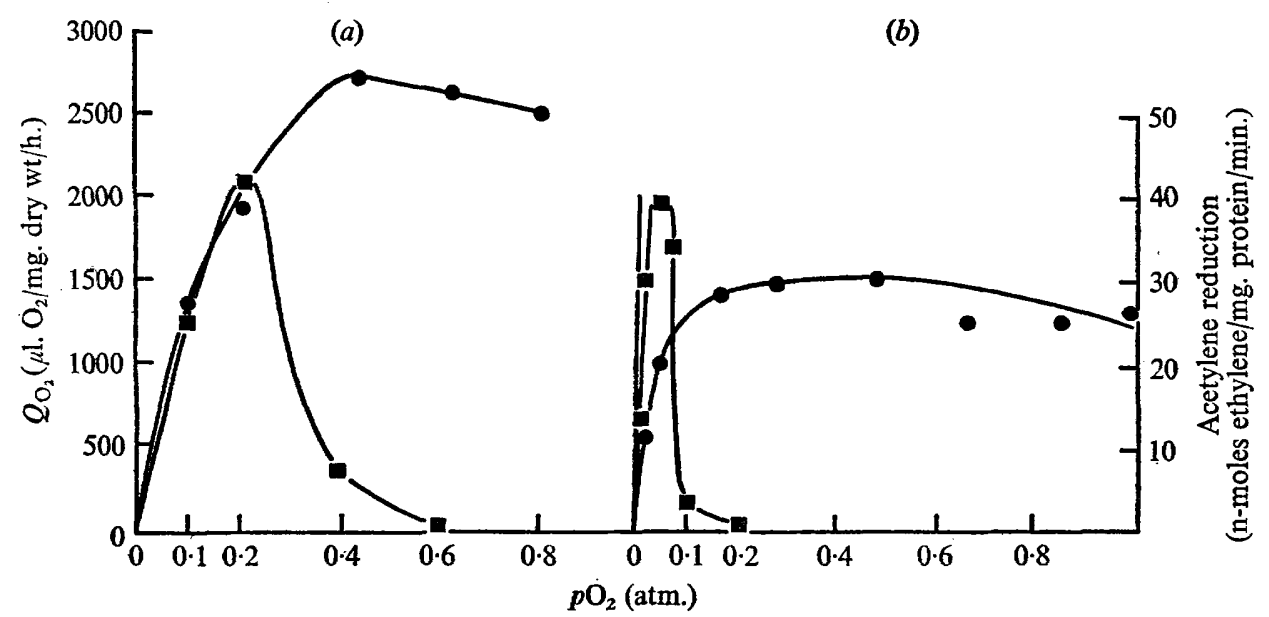

Fig. 2. $\mathrm{O}_{2}$ uptake (as $Q_{\mathrm{O}_{2}}$,, ) and acetylene reduction ( $\boldsymbol{\square}$ ) at various $p \mathrm{O}_{2}$ values by $\mathrm{I} \mathrm{ml}$. samples of continuous cultures of Azotobacter chroococcum $\left(D=0 \cdot 2\right.$ h. $\left.^{-1}\right)$. In $(a)$ organisms grown with $0.55 \mathrm{~atm} . \mathrm{O}_{2}$; in $(b)$ grown with $0.09 \mathrm{~atm} . \mathrm{O}_{2}$. (For detailed conditions see text.)

Figures $2(a)$ and $(b)$ show that, over 20 min., high $p \mathrm{O}_{2}$ depressed the respiration rates only slightly. Acetylene reduction measured under similar conditions was much more sensitive to elevated $p \mathrm{O}_{2}$ and was completely inhibited in populations tested at $p \mathrm{O}_{2}$ values which gave their maximum respiration rate. The population grown at a $p \mathrm{O}_{2}$ of $0.09 \mathrm{~atm}$. showed acetylene reduction up to $0.15 \mathrm{~atm}$. with a maximum at $0.05 \mathrm{~atm}$.; the population grown at $0.55 \mathrm{~atm}$. showed activity up to $0.55 \mathrm{~atm}$. with a maximum at $0.2 \mathrm{~atm}$. oxygen. The maximum specific activities at optimal $p \mathrm{O}_{2}$ values were the same in both cases.

\section{Effect of $\mathrm{pO}_{2}$ on cytochrome content}

Azotobacter vinelandii was reported to possess cytochromes $c_{4}, c_{5}, b_{1}, a_{1}, a_{2}$ and $o$ (Jones \& Redfearn, 1967), although cytochrome $o$ was difficult to establish because it was usually only present in traces. Table I shows that, with increased $p \mathrm{O}_{2}$, the cytochrome $a_{2}$ content of the organisms increased in parallel with the increase in 
$Q_{\mathrm{O}_{2}}$ mentioned earlier. The $\alpha$ peaks of cytochromes $c_{4}+c_{5}$ showed a slight maximum at $\mathrm{O}$. I atm. oxygen, the $\alpha$ peaks of cytochrome $b_{1}$ appeared as a shoulder on the $c_{4}+c_{5}$ peak and was difficult to measure in these conditions.

\section{Effect of $\mathrm{N}_{2}$ on cytochromes}

Several reports have been published suggesting that the cytochromes of $\mathrm{N}_{2}$-fixing Azotobacter species interact with $\mathrm{N}_{2}$ (Wilson, I958; Ivanov, Sitonite \& Belov, I965; Ivanov, Matkhanov, Belov \& Gogoleva, I967; Ivanov et al. 1968). Dalton \& Postgate $(\mathrm{I} 969 \mathrm{~b})$ found no such interaction with carbon-limited populations of Azotobacter chroococcum. Since growth $\mathrm{pO}_{2}$ might influence the response of $\mathrm{N}_{2}$, we tested populations grown at 0.09 and $0.55 \mathrm{~atm}$. in the following manner. Azotobacter chroococcum from the effluent vessel of a continuous culture was resuspended at I I mg. dry wt/ml. $0.025 \mathrm{M}$-tris- $\mathrm{HCl}$ buffer, $\mathrm{pH} 7 \cdot 4$. The preparation was gassed successively in a diffuse reflectance cell with high purity $\mathrm{H}_{2}, \mathrm{Ar}, \mathrm{N}_{2}$ and $\mathrm{O}_{2}$ (Air Products Ltd); the fully reduced spectrum was finally checked by adding dithionite after the $\mathrm{O}_{2}$ treatment. Hydrogen gave the fully reduced spectrum; Ar did not give any change, nor did $\mathrm{N}_{2}$. Oxygen gave a $70 \%$ decrease in the $\beta$ peaks of cytochromes $c_{4}+c_{5}$ and $b_{1}$, a $90 \%$ decrease in their $\alpha$ peaks and a shift in their combined $\gamma$ peaks from 420 to $4 \mathrm{I} 2 \mathrm{~nm}$.

\section{Effect of $\mathrm{NH}_{4}$ on cytochromes}

Dalton \& Postgate ( $1969 b$ ) observed no substantial differences between the cytochrome patterns of $\mathrm{N}_{2}$-grown and $\mathrm{NH}_{4}{ }^{+}$-grown continuous cultures in otherwise comparable conditions. Knowles \& Redfearn (I968) observed considerable differences in cytochrome contents of subcellular particles from urea- or $\mathrm{N}_{2}$-grown batch cultures of Azotobacter vinelandii, so we repeated Dalton \& Postgate's experiment using a different $\mathrm{pO}_{2}$. Azotobacter chroococcum from an $\mathrm{NH}_{4}{ }^{+}$-grown $\left(\mathrm{I} \cdot 5 \mathrm{~g} . \mathrm{NH}_{4} \mathrm{Cl} / \mathrm{l}\right.$.) continuous culture, $D=0.2 \mathrm{~h} . .^{-1}$ under $0.7 \mathrm{~atm}$. argon $+0.3 \mathrm{~atm} . \mathrm{O}_{2}$, had a cytochrome spectrum similar to that of bacteria from the nitrogen-deficient medium grown at the same dilution rate but with $0.7 \mathrm{~atm} . \mathrm{N}_{2}+0.3 \mathrm{~atm} . \mathrm{O}_{2}$.

\section{Michaelis constant for acetylene reduction by whole bacteria}

Samples of the cultures grown at low and high $\mathrm{pO}_{2}$ were tested with argon $+\mathrm{O}_{2}$ at various partial pressures of acetylene. The $K_{m}$ values were similar and within the range $0.0028 \pm 0.0005 \mathrm{~atm}$. acetylene. Plots of reciprocal velocity against reciprocal substrate concentration showed that nitrogen acted as a competitive inhibitor of acetylene reduction. The $K_{n}$ values were independent of the $p \mathrm{O}_{2}$ at which they were determined. A few tests with batch cultures gave similar $K_{m}$ values.

\section{Reversible inhibition of acetylene reduction by $\mathrm{O}_{2}$}

Samples of Azotobacter chroococcum from continuous cultures grown at the high or the low $p \mathrm{O}_{2}$ value were exposed for 5 to $10 \mathrm{~min}$. in atmospheres of $p \mathrm{O}_{2}$ just sufficient to inhibit acetylene reduction completely when shaken at 75 strokes/min., amplitude $4 \mathrm{~cm}$. If the $p \mathrm{O}_{2}$ value was then altered to the optimum for that population, the reduction of acetylene was immediately resumed, usually completely but sometimes up to $30 \%$ below the original specific rate (Fig. $3 a$ ). This is the 'switch on' and 'switch off' process reported by Drozd \& Postgate (1970). The process was too 
rapid for destruction and resynthesis of nitrogenase to be involved; this point was nevertheless checked by experiments in which 'switch off' and 'switch on' were induced in the presence of $75 \mu \mathrm{g}$. chloramphenicol $/ \mathrm{ml}$. to inhibit protein synthesis. The drug had no effect at all on either step in the process. As would be expected, both from our work and that of Yates (1970), culture samples shaken at a fixed $p \mathrm{O}_{2}$ decreased in activity when shaken more rapidly; on lowering the shaking to

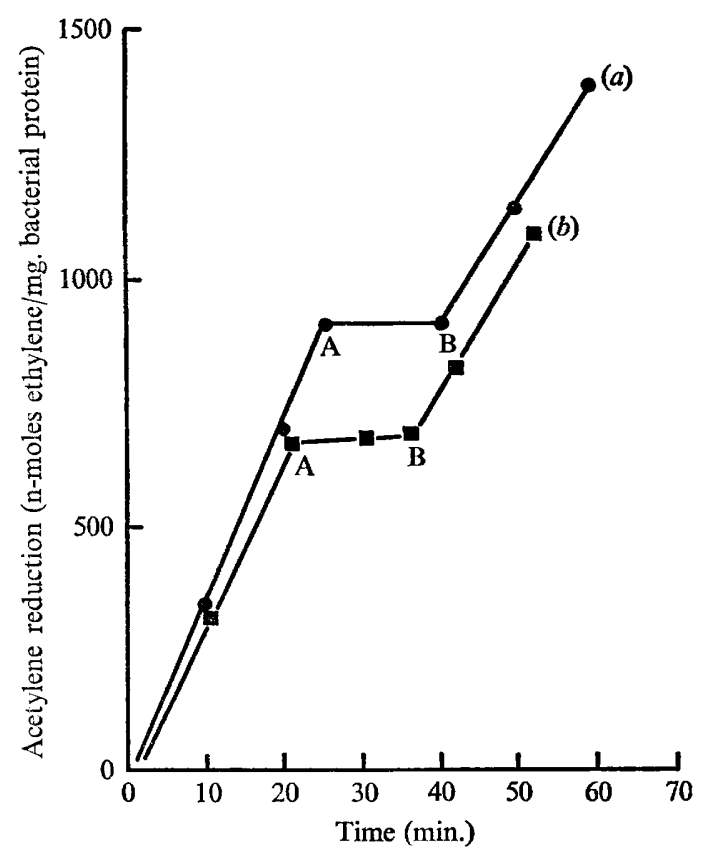

Fig. 3. 'Switch on' and 'switch off' of acetylene reduction by oxygenation in Azotobacter chroococcum. In the first experiment oxygenation was altered by increasing the $p \mathrm{O}_{2}(\boldsymbol{\odot})$. A sample $\left(2 \mathrm{ml}\right.$.) from a continuous culture $\left(D=0.2 \mathrm{~h} .{ }^{-1}, p \mathrm{O}_{2}=0.09 \mathrm{~atm}\right.$.) was shaken in a $25 \mathrm{ml}$. conical flask at $\mathrm{I} 50$ strokes/min., amplitude $4 \mathrm{~cm}$., at $30^{\circ}$ under $0.05 \mathrm{~atm}$. $\mathrm{O}_{2}+9.95 \mathrm{~atm}$. Ar+0.03 atm. $\mathrm{C}_{2} \mathrm{H}_{2}$. At $\mathrm{A}$ the flask was opened, flushed and resealed within 20 sec. with $0.2 \mathrm{~atm} . \mathrm{O}_{2}+0.8 \mathrm{~atm}$. Ar $+0.03 \mathrm{~atm} . \mathrm{C}_{2} \mathrm{H}_{2} ;$ at $\mathrm{B}$ it was returned to the original atmosphere by a similar procedure. In the second experiment oxygenation was altered by increasing the shaker speed and amplitude ( $\boldsymbol{\sigma})$. A sample (details as for first experiment) was shaken at 75 strokes $/ \mathrm{min}$., amplitude $\mathrm{I} \cdot 5 \mathrm{~cm}$., at $30^{\circ}$ under $0.2 \mathrm{~atm}$. $\mathrm{O}_{2}+0.8 \mathrm{~atm}$. $\mathrm{Ar}+0.03 \mathrm{~atm} . \mathrm{C}_{2} \mathrm{H}_{2}$. The shaking was changed to 150 strokes $/ \mathrm{min}$., amplitude $4 \mathrm{~cm}$., at $\mathrm{A}$ and returned to the original at $\mathrm{B}$.

the original frequency the activity returned immediately, usually completely, but never more than $30 \%$ below the original (Fig. $3 b$ ). Consistent with the work described earlier, the lower the $Q_{\mathrm{O}_{2}}$ of the population, the more readily was acetylene reduction suppressed by oxygen. These observations show that 70 to $100 \%$ of the inhibitory effect of oxygen was immediately reversible.

Irreversible inhibition of acetylene reduction by $\mathrm{O}_{2}$

Part of the inhibition by oxygen was sometimes not reversible. To study the question further, a continuous culture of Azotobacter chroococcum was set up at $D=0.2 \mathrm{~h}^{-1}, p \mathrm{~N}_{2}=0.8, p \mathrm{O}_{2}=0.2 \mathrm{~atm}$. and the atmosphere replaced by pure 
$\mathrm{O}_{2}$ for $30 \mathrm{~min}$. or $\mathrm{I} \mathrm{h}$. Nearly all the organisms in the growth vessel were harvested and the remainder left to grow at $0 \cdot 2 \mathrm{~atm} . \mathrm{O}_{2}$ again. Extracts of the harvested organisms had no acetylene-reducing activity; populations from the same continuous culture treated similarly, on a different occasion, but with pure argon in place of the $\mathrm{O}_{2}$, gave extracts showing $80 \%$ of the acetylene-reducing activity of undamaged organisms harvested from the culture. Addition of purified 'fraction 2' to extracts of the oxygen-treated population restored $90 \%$ of the original activity. These findings are illustrated in Table 2, which includes a further control, in which a population which had been grown with sufficient $\mathrm{NH}_{4}{ }^{+}$to repress nitrogenase synthesis was exposed to argon, to show that the acetylene-reducing activity which was recovered was not due to use of impure 'fraction 2 '.

Table 2. Restoration of acetylene-reducing activity to extracts of oxygenated Azotobacter chroococcum cultures by addition of 'fraction 2'

Continuous cultures of $\mathrm{N}_{2}$-fixing Azotobacter chroococcum were interrupted while the contents of the growth vessel were exposed to the gases indicated, harvested and the acetylene-reducing activities of extracts determined. For details see text. Final assay mixture contained io $\mu$ moles $\mathrm{MgCl}_{2}, 5 \mu$ moles ATP, $40 \mu$ moles creatine phosphate (Sigma Chemical Co., London, S.W.6), $25 \mu$ moles tris-HCl buffer, pH $7 \cdot 4,0.2 \mathrm{mg}$. creatine phosphokinase (E.C. 2.7.3.2, Sigma, London), $20 \mu$ moles $\mathrm{Na}_{2} \mathrm{~S}_{2} \mathrm{O}_{4}, 0.5 \mathrm{ml}$. extract ( $8.5 \mathrm{mg}$. protein $/ \mathrm{ml}$.), $0.025 \mathrm{ml}$. 'fraction 2' ( $0.2 \mathrm{mg}$. protein) when added, $\mathrm{H}_{2} \mathrm{O}$ to I.5 ml. The reaction was started by adding $0.2 \mathrm{ml}$. acetylene and stopped after Io min. with $0.1 \mathrm{ml}$. $30 \%$ trichloroacetic acid.

\section{Treatment}

$\mathrm{Ar}+0.2 \mathrm{~atm} . \mathrm{O}_{2}$ for $30 \mathrm{~min}$.

Ar for $30 \mathrm{~min}$.

$\mathrm{O}_{2}$ for $30 \mathrm{~min}$.

Grown with $\mathrm{NH}_{4}{ }^{+}$
Addition

None

None

None

'Fraction 2'

None

'Fraction 2' n-mole ethylene formed/mg. protein/ min.

20

I6

2

18

o

3

\section{DISCUSSION}

\section{Respiratory protection of nitrogenase in Azotobacter chroococcum}

Evidence for increased efficiency of nitrogen fixation (mg. $\mathrm{N}$ fixed $/ \mathrm{g}$. carbon source consumed) by azotobacters at low $p \mathrm{O}_{2}$ values, and concomitant inefficiency at high $p \mathrm{O}_{2}$ values, has been reported by several workers (Parker, 1954; Parker \& Scutt, 1960 ; Phillips \& Johnson, 196r; Dalton \& Postgate, 1969a). As a rationalization of the effects of nutritional status on the oxygen sensitivity of continuous cultures, Dalton \& Postgate (1969a) proposed that respiration in Azotobacter chroococcum, apart from its normal metabolic function, played a part in protecting functional nitrogenase from damage by oxygen. Our findings logically support their view: culture of $A$. chroococcum at low $p \mathrm{O}_{2}$ and high $p \mathrm{O}_{2}$ values led to no differences in the nitrogenase contents of the populations (as expressed in their maximum rates of acetylene reduction) but influenced markedly the $p \mathrm{O}_{2}$ value at which the maximum rate was obtained. We found a direct relationship between optimal $p \mathrm{O}_{2}$ for acetylene reduction and $Q_{\mathrm{O}_{2}}$ of the population: the greater the $Q_{\mathrm{o}_{2}}$, the more environmental oxygen the population could tolerate before inhibition of acetylene reduction appeared. This was true of 
samples of cultures grown at high and at low $\mathrm{OO}_{2}$ values and tested with acetylene over a range of $p \mathrm{O}_{2}$ values and of samples tested at various shaking frequencies at the partial pressure of $\mathrm{O}_{2}$ in air; it was also true of the effect of ambient molarities of dissolved oxygen (as registered by oxygen electrodes) on acetylene reduction by the actual 'continuous' cultures (which ceased to be continuous for the duration of the experiment).

\section{Reversible oxygen inhibition and 'conformational protection'}

Our observations that $\mathrm{O}_{2}$ inhibition, in both high and low oxygen populations, is 70 to $100 \%$ reversible if exposure to oxygen has not been prolonged is direct evidence for a response too rapid to involve damage to and resynthesis of enzymes or portions of enzymes. Our experiments with chloramphenicol, which inhibits nitrogenase synthesis in Azotobacter vinelandii (Strandberg \& Wilson, 1968) support this view. Rapidly reversible $\mathrm{O}_{2}$ inhibition of nitrate reductase activity, also without protein synthesis, occurs in anaerobically grown cultures of Aerobacter aerogenes (Pinchinoty, 1963) and the tetrathionate reductase activity of a similarly grown unidentified coliform bacterium (Pinchinoty \& Bigliardi-Rouvier, r963) is also oxygen-sensitive. Pinchinoty attributed these responses to an auto-oxidizable flavin at which $\mathrm{O}_{2}$ competed with the inorganic acceptors for electrons. Competition by $\mathrm{O}_{2}$ at the prosthetic site of such enzymes would lead to similar responses. Competition for electrons at the prosthetic site of nitrogenase, or at an auto-oxidizable electron carrier, might equally well account for the 'switch on-switch off' effects described in this paper, but other evidence argues against this view. Since the purified enzyme is oxygen-sensitive yet the crude form is not (Bulen \& LeComte, I966; Kelly, 1969a, $b$ ), this indicates that a 'protected' conformation does exist; in populations from batch culture, 'switch on' is not immediate (Drozd \& Postgate, I970), which a kinetic interpretation of the process would require it to be. Though we accept that there is still no direct evidence that the conformation of the intracellular nitrogenase changes (Dalton \& Postgate, I969a,b), certainly some event takes place which prevents interaction with oxygen, acetylene and, by implication, nitrogen. Oppenheim \& Marcus (1970) and Oppenheim, Fisher, Marcus \& Wilson (1970) showed that $\mathrm{N}_{2}$-fixing $A$. vinelandii is particularly rich in internal membranes and that insoluble oxygen-tolerant enzyme preparations are obtained by a method which yields nitrogenase associated with membrane material; osmotic rupture yielded preparations not associated with membrane which were both soluble and oxygen-sensitive. These two forms of nitrogenase might correspond to the 'switched off' and 'switched on' states of the enzyme. 'Conformational protection', as we shall continue to call it, was sometimes less than perfect in that up to $30 \%$ of the original activity was sometimes not restored, and exposure to pure oxygen induced irreversible oxygen damage directly attributable to the oxygen-sensitive component ('fraction 2') of nitrogenase. Kelly (1969b) reported that the normally air-stable particulate nitrogenase from Azotobacter chroococcum, which we regard as representative of the conformationally protected enzyme complex in vivo, lost about $75 \%$ activity over $30 \mathrm{~min}$. in pure $\mathrm{O}_{2}$. Both our work and that of Kelly (1969a,b) are consistent with the report of Strandberg $\&$ Wilson (1968) that prolonged ( $4 \mathrm{~h}$.) shaking of $A$. vinelandii cultures in air decreased $\mathrm{N}_{2}$-fixing activity of extracts 28 -fold and that synthesis of nitrogenase by $\mathrm{NH}_{4}{ }^{+}$-limited A. vinelandii was inhibited by hyperbaric ( $0.4 \mathrm{~atm}$.) oxygen but not by air. 


\section{Effect of growth conditions on cytochromes in nitrogen fixation}

The cytochrome patterns obtained on altering the growth $\mathrm{pO}_{2}$ showed that, in $\mathrm{O}_{2}$-limiting conditions (below $p \mathrm{O}_{2}=0.09 \mathrm{~atm}$.), the $c_{4}+c_{5}$ level was the same as in $\mathrm{N}_{2}$-limited populations, but the decrease in $a_{2}$ content with decrease in $p \mathrm{O}_{2}$ continued. This is contrary to the report of Swank \& Burris (I969) that the $c_{4}+c_{5}$ content of $\mathrm{O}_{2}$-limited Azotobacter vinelandii was twice that of populations which were presumably $\mathrm{N}_{2}$-limited. Lisenkova \& Khmel (1967) measured the cytochrome content of whole $A$. vinelandii from a continuous culture growing at $D=0.3 \mathrm{~h}^{-1}$, but their maximum $Q_{\mathrm{O}_{2}}$ values are so low $\left(430 \mu \mathrm{l} . \mathrm{O}_{2} / \mathrm{mg}\right.$. dry wt/h.) that the populations must have been $\mathrm{O}_{2}$-limited and not $\mathrm{N}_{2}$-limited in the sense used by Dalton \& Postgate (I969 $b$ ). Comparisons of their results and ours are therefore difficult. Like Dalton \& Postgate (1969 b) and consistent with the experiments of Swank \& Burris (1969) using bacterial extracts, we could obtain no evidence for direct involvement of cytochromes in nitrogen fixation either from the cytochrome patterns of organisms grown in various conditions or by direct tests for cytochrome oxidation by $\mathrm{N}_{2}$.

We acknowledge useful critical comments by Dr M. G. Yates during preparation of this manuscript.

\section{ERR A T A}

Two publications from the laboratory contain mistakes due to oversight in preparing the manuscripts. They are:

Dalton \& Postgate (1969b), Fig. 2, p. 313:

The rate of ethylene production should be $/ \mathrm{min}$., not $/ \mathrm{h}$.

Biggins \& Postgate (1969), Fig. I, p. I87:

The figures for $\mu$ moles ethylene produced should be divided by 45 .

J. R. Postgate and his co-authors apologize for any confusion they may have caused.

\section{REFERENCES}

BAKER, K. (I968). Low cost continuous culture apparatus. Laboratory Practice 17, 817.

Biggins, D. R. \& Postgate, J. R. (I969). Nitrogen fixation by cultures and cell-free extracts of Mycobacterium flavum 301. Journal of General Microbiology 56, 181-193.

Bulen, W. A. \& Le Comte, J. R. (r966). The nitrogenase system from Azotobacter: two enzyme requirement for $\mathrm{N}_{2}$ reduction, ATP-dependent $\mathrm{H}_{2}$ evolution, and ATP hydrolysis. Proceedings of the National Academy of Sciences of the United States of America 56, 979.

Dalton, H. \& Postgate, J. R. (I969a). Effect of oxygen on growth of Azotobacter chroococcum in batch and continuous cultures. Journal of General Microbiology 54, 463 .

Dalton, H. \& Postgate, J. R. (I969 b). Growth and physiology of Azotobacter chroococcum in continuous culture. Journal of General Microbiology 56, 307.

Drozd, J. W. \& PostGate, J. R. (I970). Interference by oxygen in the acetylene-reduction test for aerobic nitrogen-fixing bacteria. Journal of General Microbiology 60, 427-429.

Gornall, A. G., Bardawill, C. J. \& David, M. M. (I949). Determination of serum proteins by means of the biuret reaction. Journal of Biological Chemistry $\mathbf{1 7 7}, 75 \mathrm{I}$.

Hardy, R. W. F., Holsten, R. D., Jackson, E. K. \& Burns, R. C. (1968). The acetylene-ethylene assay for $\mathrm{N}_{2}$ fixation: Laboratory and field evaluation. Plant Physiology 43, I 85 .

Ivanov, I. D., Sitonite, Y. P. \& Belov, Y. M. (1965). Nitrogen fixation as a hydrogen accepting process. Mikrobiologiya 34, 193.

Ivanov, I. D., Matkhanov, G. I., Belov, Y. M. \& Gogoleva, T. V. (I967). Reduction of molecular nitrogen in model systems. Mikrobiologiya 36, 205. 
Ivanov, I. D., Moshkovskit, Y. S., Stukan, R. A., Matkhanov, G. I., Mardanyan, S. S. \& Belov, Y. M. (1968). Investigation of $\gamma$-resonance spectra of nitrogen-fixing bacteria. Mikrobiologiya $37,407$.

KeLly, M. (1969a). Some properties of purified nitrogenase of Azotobacter chroococcum. Biochimica et Biophysica Acta $\mathbf{1 7 1} 9$.

KeLlY, M. (1969b). Comparisons and cross reactions of nitrogenase from Klebsiella pneumoniae, Azotobacter chroococcum and Bacillus polymyxa. Biochimica et Biophysica Acta 19I, 527.

Jones, C. W. \& RedfEARn, E. R. (1967). The cytochrome system of Azotobacter vinelandii. Biochimica et Biophysica Acta 143, 340.

KNowles, C. J. \& RedFEARN, E. R. (I968). The effect of combined nitrogen sources on the synthesis and function of electron transport system of Azotobacter vinelandii. Biochimica et Biophysica Acta 162, 348 .

Lisenkova, L. L. \& KHmel, I. A. (I967). Effect of cultural conditions on the cytochrome content of Azotobacter vinelandii cells. Mikrobiologiya 36, 905.

Lowry, O. H., Rosebrough, N. J., Farr, A. L. \& Randall, R. J. (195I). Protein measurement with the Folin phenol reagent. Journal of Biological Chemistry I93, 265.

Meyerhof, O. \& BurK, D. (1928). Über die Fixation des Luftstickstoffe durch Azotobakter. Zeitschrift für Physiologische Chemie (A) I39, II 7.

OpPENHeIM, J. \& MARCus, L. (1970). Correlation of ultrastructure in Azotobacter vinelandii with nitrogen source for growth. Journal of Bacteriology 1or, 286.

Oppenheim, J., Fisher, R. J., Marcus, L. \& Wilson, P. W. (1970). Properties of a soluble nitrogenase in Azotobacter. Journal of Bacteriology Ior, 292.

PARKER, C. A. (1954). Effect of oxygen on the fixation of nitrogen by Azotobacter. Nature, London I73, 780 .

PARKer, C. A. \& Scutt, P. B. (I960). The effect of oxygen on nitrogen fixation by Azotobacter. Biochimica et Biophysica Acta 38, 230.

Phillips, D. H. \& Johnson, M. J. (I961). Measurement of dissolved oxygen in fermentations. Journal of Biochemical, Microbiological and Technical Engineering 3, 277.

Pinchinoty, F. (1963). Recherches sur la nitrate-réductase d'Aerobacter aerogenes. Annales de l'Institut Pasteur, Paris 104, 394.

Pinchinoty, F. \& Bigliardi-Rouvier, J. (I963). Recherches sur la tétrathionate-réductase d'une bactérie anaérobic facultative. Biochimica et Biophysica Acta 67, 366.

Stewart, W. D., Fitzgerald, G. P. \& Burris, R. H. (I967). In situ studies on $\mathrm{N}_{2}$ fixation using the acetylene reduction technique. Proceedings of the National Academy of Sciences of the United

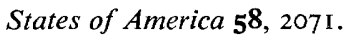

Strandberg, G. W. \& Wilson, P. W. (I968). Formation of the nitrogen-fixing enzyme system in Azotobacter vinelandii. Canadian Journal of Microbiology 14, 25.

Swank, R. T. \& BurRis, R. H. (I969). Purification and properties of cytochromes $c$ of Azotobacter vinelandii. Biochimica et Biophysica Acta $\mathbf{I 8 0}, 473$.

WILson, P. W. (1958). Asymbiotic nitrogen fixation. In Encyclopedia of Plant Physiology, p. 9. Edited by W. Ruhland. Berlin: Springer-Verlag.

YATES, M. G. (I970). Control of respiration and nitrogen fixation by oxygen and adenine nucleotides in $\mathrm{N}_{2}$-grown Azotobacter chroococcum. Journal of General Microbiology 6o, 393-40I. 